\title{
ASTAXANTHIN SYNTHESIS \\ BY XANTHOPHYLLOMYCES DENDRORHOUS DSM 5626 AND ITS ASTAXANTHIN OVERPRODUCING MUTANTS ON XYLOSE MEDIA UNDER DIFFERENT ILLUMINATION*
}

\author{
Barbara Stachowiak ${ }^{凶}$ \\ Institute of Technology of Plant Origin Food, Poznań University of Life Sciences \\ Wojska Polskiego 31, 60-624 Poznań, Poland
}

\begin{abstract}
Background. Astaxanthin is the most important and expensive carotenoid pigment used in aquaculture. Its commercial attractiveness is also related with its antioxidant potential. Xanthophyllomyces dendrorhous yeast is considered to be promising for commercial production of astaxanthin. The aim of this study was to investigate the possibility of the growth and astaxanthin production by $X$. dendrorhous strains on media containing xylose under different illumination.

Material and methods. X. dendrorhous DSM 5626 and its mutants: 10BE and 26UV were used in this study. The cultures were carried out on hydrolysed rye stillage (HS) and YM medium with xylose (YM-K). Cell concentration, total carotenoid and astaxanthin yields were assessed in 5-day cultures. The effect of illumination in the range of $0-5,000 \mathrm{~lx}$ on growth and on astaxanthin production of yeasts in cultures run on YM-K medium was also examined.

Results. For the tested yeast strains better growth parameters and astaxanthin yields were obtained on the YM-K medium, on which for all strains the highest pigment yields were recorded at 600-1,000 lx. The highest concentration of astaxanthin in cells was recorded for $26 \mathrm{UV}$ in a culture at $1,000 \mathrm{~lx}\left(0.51 \mathrm{~g} \cdot \mathrm{kg}^{-1} \mathrm{DCW}\right)$. The volume yield of the pigment regardless of strain was highest in cultures at $600 \mathrm{~lx}$. In this case 10BE was found to be the best astaxanthin producer with a yield of $2.15 \mathrm{mg} \cdot \mathrm{dm}^{-3}$.

Conclusions. Astaxanthin synthesis in X. dendrorhous DSM 5626 and its mutants was better on YM-K medium comparing to hydrolysed rye stillage. Moreover, carotenogenesis in the studied yeast strains was subjected to marked photoregulation. Illumination within the range of 600-1,000 lx promotes carotenogenesis and astaxanthin production, while exceeding a certain light capacity results in microbial cell death.
\end{abstract}

Key words: astaxanthin, culture, xylose, illumination, Xanthophyllomyces dendrorhous

\section{INTRODUCTION}

Astaxanthin - 3,3'-dihydroxy- $\beta, \beta$-carotene-4,4'-dion - is a xanthophyll, with a chemical formula of $\mathrm{C}_{40} \mathrm{H}_{52} \mathrm{O}_{4}$ and a molecular mass of $596 \mathrm{Da}$ [Goswami et al.
2010]. From an economic viewpoint, astaxanthin is the second, next to $\beta$-carotene, most important carotenoid with a global market size of \$219 million in 2007

\footnotetext{
*This work was supported by the Ministry of Science and Higher Education, Poland (grant No 2 PO6T 024 30).

『stach@up.poznan.pl 
( $29 \%$ of total carotenoid sales). It is estimated to reach $\$ 253$ million by 2015 , with an average annual growth rate of $1.8 \%$ [Schmidt et al. 2011].

Astaxanthin commercial application is connected first of all with the feed industry. At present, it is one of the most important and most expensive pigments used in aquaculture [Breithaupt 2007]. It is an obligatory component in feeds for salmon, trout and prawn, providing characteristic pigmentation of their tissues and thus influencing consumer preferences. This pigment is also an indispensable component of feed for aquarium fish and for large ornamental fish [Xu et al. 2006]. It was also shown that astaxanthin has an advantageous effect on coloration of egg yolks as well as skin and meat tissue in carcasses of broiler chickens [Takahashi et al. 2004].

Moreover, astaxanthin is thought to be responsible for the beneficial properties which prevent human diseases including cancer, certain neurodegenerative diseases such as Parkinson's and Alzheimer's disease, oculopathies (cataract, age-related macular degeneration), atherosclerosis and diabetes. It also exhibits anti-inflammatory and immunostimulatory action [Goswami et al. 2010, Pashkow et al. 2008, Yuan et al. 2011]. The beneficial effect of astaxanthin is related to the presence of coupled double bonds in the long hydrocarbon chain as well as polar hydroxyl and carbonyl groups in both ionone rings [Liu and Osawa 2007]. Due to its unique chemical structure: polarnonpolar-polar, astaxanthin can react with phospholipid head groups or water in the aqueous environment, quenching radicals from the surface of or inside the lipid bilayer of cell membrane [Pashkow et al. 2008]. It protects membrane phospholipids and other lipids against peroxidation more effectively than $\beta$-carotene and lutein [McNulty et al. 2007] and shows higher scavenging capacity against peroxyl and hydroxyl radicals than that of $\alpha$-tocopherol, lutein, lycopene and $\beta$-carotene [Rodrigues et al. 2012]. However, some literature data indicate that the antioxidant effect of astaxanthin depends on the adopted experimental model [Gramza-Michałowska and Stachowiak 2010]. Regardless of that fact, astaxanthin is proposed as a component of dietary supplements, functional food and cosmetic agents related to the prevention and control of oxidative stress. Testing results indicate that a daily dose of astaxanthin already at $5 \mathrm{mg} \cdot \mathrm{kg}^{-1}$ body weight protects the human organism against oxidative stress [Karppi et al. 2007].

Chemical synthesis is currently acknowledged as the lowest-cost production process of astaxanthin and will very likely remain the main source of this compound in animal feed. The market price of synthetic astaxanthin is around $\$ 2,000$ per kilogram, while the natural product is sold for more than $\$ 7,000$ per kilogram [Schmidt et al. 2011]. The natural preparations of astaxanthin are demanded for the cosmetic and nutraceutical market.

Xanthophyllomyces dendrorhous (the perfect state of Phaffia rhodozyma) and its astaxanthin overproducing mutants, next to algae Hematococcus pluvialis, are the most promising sources of natural astaxanthin. They may utilise different carbon substrates: glucose, maltose, sucrose, cellobiose, xylose, arabinose, lactose and many other, frequently unconventional sources [Palágyi et al. 2001]. Literature data show that higher yields of astaxanthin with $X$. dendrorhous yeast are obtained on media containing xylose than on media containing glucose or other carbon substrates [Vazquez et al. 1997, Parajó et al. 1998, Ananda and Vadlani 2010].

Xylose is a pentose and it is produced commercially by acid hydrolysis of lignocellulose materials. For this reason many research papers concern the potential production of astaxanthin using hardwood or waste from the agri-food sector, containing that substrate. Cultures of $X$. dendrorhous were run on hydrolysates of Pinus pinaster [Parajó et al. 1997], Eucalyptus globulus [Cruz and Parajó 1998], waste from maize processing [Leathers 2003], barley straw and sugar cane pulp [Montanti et al. 2011].

The application of stillage as a substrate for the production of astaxanthin is considered to be highly promising, as it would be a chance to manage this troublesome waste. Liquid stillage may be a cheap and valuable source of nutrients required for microbial growth [Krzywonos et al. 2009]. In turn, a problem is connected with the low content of dry matter and thus readily available carbon substrate. Nevertheless, fiber may be a source of this substrate. For this reason stillage is used in bioprocesses and it is frequently hydrolysed previous to its use.

The aim of this study was to investigate the growth and synthesis of astaxanthin by $X$. dendrorhous DSM 
5626 and its astaxanthin overproducing mutants 10BE and 26UV, obtained previously [Stachowiak 2013 a] on media containing xylose, including hydrolysed rye stillage. The influence of illumination on the production of biomass and astaxanthin in the studied yeasts in cultures on YM-K medium were also investigated.

\section{MATERIAL AND METHODS}

\section{Microorganisms}

The parental Xanthophyllomyces dendrorhous DSM 5626 (= ATCC 24202 and CBS 5905) strain from Deutche Sammlung von Mikroorganismen and Zellkulturen (Braunschweig), and its two astaxanthin hyperproducing mutants, $10 \mathrm{BE}$ and $26 \mathrm{UV}$, generated at our laboratory, were used in this study. The mutant $10 \mathrm{BE}$ was isolated from medium with ethidium bromide at $1 \mathrm{mg} \cdot \mathrm{cm}^{-3}$. The mutant $26 \mathrm{UV}$ was obtained as result of exposure of parental yeast to UV radiation $(\lambda=254 \mathrm{~nm})$ for $5 \mathrm{~min}$ [Stachowiak $2013 \mathrm{a}$ ]. Yeasts were maintained on YM agar slants $(1 \%$ glucose, $0.5 \%$ peptone, $0.3 \%$ malt extract, $0.3 \%$ yeast extract, $2 \%$ agar for solid, $\mathrm{pH} 5.0$ ) at $4^{\circ} \mathrm{C}$ until used.

\section{Test media}

- YM-K (YM medium with xylose): in the classical medium YM, glucose was replaced by xylose. The YM-K medium composition was as follows: malt extract (BTL, Łódź, Poland) - 3 g; yeast extract - $3 \mathrm{~g}$ (BTL, Poland); peptone (Difco Laboratories Inc., France) $-5 \mathrm{~g}$; xylose (BTL, Poland) $-10 \mathrm{~g}$, distilled water $-1 \mathrm{dm}^{3} ; \mathrm{pH}-5.0$.

- HS (hydrolysed rye stillage): stillage from the Turew distillery (TOP FARMS, Poland) was treated with commercial cellulases/xylanases (OPTI$\mathrm{MASH}^{\mathrm{TM}} \mathrm{VR}$, Genencor International) at a dose recommended by the producer $(1000: 3 \mathrm{v} / \mathrm{v})$ for 1 hour at $55^{\circ} \mathrm{C}$, at $\mathrm{pH}=4.5$, under dynamic conditions $(150 \mathrm{rpm})$. Solids were removed from hydrolysed stillage by centrifugation at 2,320 $\mathrm{g}$ for 20 min; $\mathrm{pH}-5.0$.

\section{Cultivation}

Yeast strains kept on agar slants were cultivated twice on a liquid test medium. Cultures were grown for 4 days at $22^{\circ} \mathrm{C}$ in $250-\mathrm{cm}^{3}$ Erlenmeyer flasks (working capacity of $80 \mathrm{~cm}^{3}$, including $5 \%$ inoculum) with constant agitation (250 rpm) under illumination of 600 lx. Next, the cultures were run for 120 hours under identical conditions as those given above, and at different illumination levels of 0-5,000 lx.

Lamps emitting light close to natural (Osram, Germany) were used as light sources. Four 18W/77 lamps and four 18W/840 LUMILUX COOL WHITE lamps placed alternately in one frame were applied. Light intensity was controlled using a TES 1335 luxmeter (Tes Electrical Electronic Corp.).

\section{Carotenoid extraction and analysis}

Pigments from yeast cells were isolated as follows: $10 \mathrm{~cm}^{3}$ of culture were centrifuged at $2,000 \mathrm{~g}$ for $15 \mathrm{~min}$, the cell pellet was washed twice with distilled water and suspended in $5 \mathrm{~cm}^{3}$ of DMSO (Sigma-Aldrich, France) preheated to $55^{\circ} \mathrm{C}$. The entire volume was vortexed for $30 \mathrm{~s}$ and next $5 \mathrm{~cm}^{3}$ of the hexane fraction from petroleum (POCh, Gliwice, Poland) was added. The volume was again vortexed for $30 \mathrm{~s}$ and $20 \% \mathrm{NaCl}$ (BTL, Poland) aqueous solution was added in batches at $0.5 \mathrm{~cm}^{3}$. The hexane phase with pigments was separated by centrifugation at $2,000 \mathrm{~g}$ for $15 \mathrm{~min}$ and recovered.

Total carotenoid, astaxanthin yields and sugar contents in samples were determined with a Waters Alliance HPLC System 2695 (Milford, MA, USA) with PAD detection (Waters Z690). Analysis conditions of pigments were described by Stachowiak [2013b] and sugar analyses were described by Szwengiel et al. [2007].

Biomass was measured by DCW (dry cell weight). Total nitrogen content was analysed by the Kjeldahl method and total carbon content was determined by Dr Lange cuvette test [Handbook... 2000].

\section{Statistical analysis}

All experiments were performed in triplicate. Statistical calculations were made in the Statistica 6.0 and MS Excel 2003 programs.

\section{RESULTS AND DISCUSSION}

\section{Development of yeasts and production of carotenoids on test media with xylose}

At first stage yeasts were cultured on YM-K and HS media at a constant illumination intensity of 
600 lx. The detailed profile of sugars and their contents for YM-K medium were as follows: glucose $\left(0.6 \mathrm{~g} \cdot \mathrm{dm}^{-3}\right)$, xylose $\left(10 \mathrm{~g} \cdot \mathrm{dm}^{-3}\right)$, maltose $\left(1.3 \mathrm{~g} \cdot \mathrm{dm}^{-3}\right)$; total $-11.9 \mathrm{~g} \cdot \mathrm{dm}^{-3}$. In the case of HS medium, the contents of sugars were: glucose $\left(5.3 \mathrm{~g} \cdot \mathrm{dm}^{-3}\right)$, xylose $\left(11.5 \mathrm{~g} \cdot \mathrm{dm}^{-3}\right)$, maltose $\left(3.7 \mathrm{~g} \cdot \mathrm{dm}^{-3}\right)$; total $-20.5 \mathrm{~g} \cdot \mathrm{dm}^{-3}$. Therefore, for both media, xylose was the main carbon substrate. All identified sugars are readily metabolised by $X$. dendrorhous DSM 5626 and tested mutants [Palágyi et al. 2001, Stachowiak 2012].

For all yeasts better growth was recorded in cultures on the YM-K medium (Table 1). In this case the biomass yield was $15-20 \%$ higher than those recorded in cultures on hydrolysed stillage and values of $Y_{x / s}$ on YM-K medium were over two times higher. Upon completion of cultures in the YM-K medium total sugar consumption was $80 \%$ regardless of the strain and only the presence of xylose was found. Sugars were used in $100 \%$ in yeast cultures on hydrolysed stillage.

On YM-K medium, 50\% higher cell yields $\left(\mathrm{g} \cdot \mathrm{kg}^{-1}\right.$ DCW) and volume yields of astaxanthin $\left(\mathrm{mg} \cdot \mathrm{dm}^{-3}\right)$ were recorded for the parental strain (Table 1). In the case of both mutants the cell yield of astaxanthin was approx. $40 \%$ higher in comparison to the culture on stillage, while the volume yield amounted to $50 \%$.

Table 1. Effect of medium composition on growth parameters and carotenoid production by Xanthophyllomyces dendrorhous DSM 5626 and its mutants

\begin{tabular}{|c|c|c|c|}
\hline Parameter & DSM 5626 & $10 \mathrm{BE}$ & $26 U V$ \\
\hline \multicolumn{4}{|l|}{ YM-K medium } \\
\hline $\mathrm{DCW}, \mathrm{g} \cdot \mathrm{dm}^{-3}$ & $5.70 \pm 0.18$ & $5.47 \pm 0.38$ & $5.10 \pm 0.10$ \\
\hline$Y_{X / S}, g \cdot g^{-1}$ & $0.58 \pm 0.02$ & $0.55 \pm 0.02$ & $0.52 \pm 0.03$ \\
\hline \multicolumn{4}{|c|}{ Carotenoids, $\mathrm{mg} \cdot \mathrm{dm}^{-3}$} \\
\hline- total & $1.67 \pm 0.09$ & $2.26 \pm 0.11$ & $1.94 \pm 0.22$ \\
\hline - astaxanthin & $1.60 \pm 0.07$ & $2.15 \pm 0.14$ & $1.82 \pm 0.22$ \\
\hline \multicolumn{4}{|c|}{ Carotenoids, $\mathrm{g} \cdot \mathrm{kg}^{-1} \mathrm{DCW}$} \\
\hline- total & $0.29 \pm 0.01$ & $0.41 \pm 0.01$ & $0.38 \pm 0.02$ \\
\hline - astaxanthin & $0.28 \pm 0.01$ & $0.39 \pm 0.01$ & $0.36 \pm 0.03$ \\
\hline Astaxanthin, $\%$ & $96 \pm 0.79$ & $95 \pm 0.24$ & $94 \pm 0.53$ \\
\hline \multicolumn{4}{|l|}{ HS medium } \\
\hline $\mathrm{DCW}, \mathrm{g} \cdot \mathrm{dm}^{-3}$ & $4.83 \pm 0.48$ & $4.43 \pm 0.31$ & $4.24 \pm 0.57$ \\
\hline$Y_{X / S}, g \cdot g^{-1}$ & $0.24 \pm 0.01$ & $0.22 \pm 0.02$ & $0.21 \pm 0.02$ \\
\hline \multicolumn{4}{|c|}{ Carotenoids, $\mathrm{mg} \cdot \mathrm{dm}^{-3}$} \\
\hline- total & $0.72 \pm 0.02$ & $1.15 \pm 0.08$ & $1.08 \pm 0.06$ \\
\hline - astaxanthin & $0.68 \pm 0.02$ & $1.03 \pm 0.03$ & $0.98 \pm 0.05$ \\
\hline \multicolumn{4}{|c|}{ Carotenoids, $\mathrm{g} \cdot \mathrm{kg}^{-1} \mathrm{DCW}$} \\
\hline- total & $0.15 \pm 0.01$ & $0.26 \pm 0.02$ & $0.25 \pm 0.01$ \\
\hline - astaxanthin & $0.14 \pm 0.01$ & $0.23 \pm 0.03$ & $0.23 \pm 0.02$ \\
\hline Astaxanthin, \% & $94 \pm 2.50$ & $90 \pm 2.15$ & $91 \pm 0.52$ \\
\hline
\end{tabular}


Astaxanthin was the main pigment produced by all tested yeasts. Its share in the total carotenoids was very high and amounted to $90-96 \%$ depending on the strain and composition of the medium. A slightly lower share of astaxanthin in total carotenoids was recorded in cultures run on stillage.

In the presented results hydrolysed rye stillage turned out to be a relatively poor medium for growth and astaxanthin production by tested yeasts. It may result from many factors, the most important being the initial $\mathrm{C} / \mathrm{N}$ ratio, the initial sugar concentration and oxygen supply. Literature data indicate that a high initial $\mathrm{C} / \mathrm{N}$ ratio promotes the production of carotenoids and fatty acids (both compounds are synthesized via the mevalonate pathway) however, it is accompanied by a limited protein synthesis, resulting in a low biomass yield [Hu et al. 2005]. It is suggested that excess C, ATP and NADPH formed as a result of limited protein synthesis is used by yeasts to produce carotenoids and fatty acids [Flores-Cotera et al. 2001]. On HS medium used in these experiments the $\mathrm{C} / \mathrm{N}$ ratio was 6.78 , while in the case of $\mathrm{YM}-\mathrm{K}$ it was 1.54. A lower yield of yeast biomass was actually obtained on HS medium for all tested strains (at complete sugar consumption) when compared to YM-K medium (at $80 \%$ sugar consumption), although the differences were not spectacular. However, in yeast cultures on HS medium lower cell yields of total carotenoids were produced, with the yield of astaxanthin reduced by $50 \%$ depending on the strain. Vustin et al. [2004] indicated that the initial $\mathrm{C} / \mathrm{N}$ ratio below 5 has a negative effect on the synthesis of carotenoids in $X$. dendrorhous, so poor growth of studied yeasts, low values of $Y_{X / S}$ and low yields of astaxanthin recorded in this study in cultures on HS might be the result from the deficit of some compounds, e.g. specific amino acids, macro- and microelements or vitamins. Some of them (e.g. vitamin B) are essential for the appropriate development of $X$. dendrorhous. Although vitamin B complex is present in the stillage [Krzywonos et al. 2009], following enzymatic hydrolysis stillage was centrifuged and all solids were removed, including also residual yeast, being a source of nitrogen and vitamins B. Such prepared medium was most probably too deficient in substrates other than carbon and in biostimulants in contrast to YM-K medium, which completely covered the nutritional requirements for yeast.

A decisive effect on carotenogenesis in the case of $X$. dendrorhous is also found for the initial sugar concentration and oxygen supply. Xanthophyllomyces dendrorhous is Crabtree-positive and a change from aerobic metabolism to aerobic fermentation occurs at a $5 \%$ concentration of sugars in the culture medium [Reynders et al. 1997]. In the tested media the initial sugar content varied. In YM-K medium it was approx. $1.2 \%$, while in HS medium it was approx. $2.05 \%$. Thus this factor should have no effects on primary metabolism in yeasts.

In turn, two-fold greater sugar concentration in HS medium could have resulted in a lower astaxanthin production in broth cultures. Ananda and Vadlani [2010] considered high viscosity of the culture medium, leading to lower diffusion of oxygen, to have been the cause of this result. When running 5-day cultures of Phaffia rhodozyma ATCC 24202 (the parental strain used in this study) on media containing whole maize stillage they obtained a very low yield of astaxanthin $\left(0.026 \mu \mathrm{g} \cdot \mathrm{g}^{-1}\right.$ of freeze-dried stillage), while $\beta$-carotene was the primary pigment produced by $P$. rhodozyma. It accounted for as much as $75 \%$ total pigments, while typically astaxanthin constituted $83-90 \%$ or even $100 \%$ of the total carotenoids of P. rhodozyma [Schmidt et al. 2011]. Under microaerophilic conditions $\beta$-carotene is accumulated at the expense of astaxanthin.

Recorded experimental results indicate that stillage is not a profitable medium for the strains tested in this study. The composition of stillage may probably be optimised, e.g. by concentration, supplementation with an adequate source of nitrogen, minerals, vitamins or other nutrients and on its basis a medium may be prepared for profitable production of astaxanthin using yeasts $X$. dendrorhous. However, each such attempt generates costs. In this study spent stillage (contained $8.6 \%$ of dry matter) was only subjected to cheap, enzymatic hydrolysis in order to increase the pool of sugars assimilated by $X$. dendrorhous. Prior to hydrolysis it was $3.8 \mathrm{~g} \cdot \mathrm{dm}^{-3}$, while yeast growth was practically negligible.

However, it needs to be stressed that growth and astaxanthin production in cultures in stillage or media enriched with stillage depend on used yeast strain. 
For example, Bon et al. [1997] in their experiments obtained a 2-fold higher yield of biomass in cultures of two wild strains of P. rhodozyma and mutant JB2 run on $70 \%$ TS (thin stillage) than on the conventional YM medium. However, only in the case of the mutant the carotenoid production was identical in TS and YM. For the wild strains a drastic reduction of pigment production on TS was observed.

The tested YM-K medium proved to be more suitable for the production of astaxanthin than stillage. For the tested strains on this medium better growth parameters and astaxanthin were obtained in comparison to YM medium with glucose [Stachowiak 2013 a]. Literature data indicate that the best results on growth parameters, astaxanthin proportion and carotenoid productivity were obtained in media containing xylose [Vazquez et al. 1997, Parajó et al. 1998, Montanti et al. 2011].

\section{The effect of illumination intensity on development of tested yeasts and carotenogenesis in cultures on YM medium with xylose}

The effect of illumination intensity on the controlled parameters in cultures run on YM-K medium is presented in Table 2. Light intensity had a significant effect on growth and carotenogenesis in the tested yeasts $(p<0.05)$. For all strains the highest yield of biomass was produced in cultures at illumination intensity of $600 \mathrm{~lx}$. Both weaker and stronger illumination intensity inhibited yeast growth. A particularly drastic effect was observed in cultures at 5,000 lx, at which practically no growth of yeasts was detected.

In the yeast cultures the yield of astaxanthin as well as total carotenoids initially increased with an increase in illumination intensity. Generally the highest yields of pigments were recorded within the range of 600-1,000 lx. The highest cellular concentration of astaxanthin was detected for mutant $26 \mathrm{UV}$ cultured at $1,000 \mathrm{~lx}$ (Table 2). Unfortunately, the biomass yield in this case was low and eventually only a slight volume yield of the pigment was obtained.

Regardless of the strain the greatest amounts of astaxanthin per $1 \mathrm{dm}^{3}$ culture were produced at $600 \mathrm{~lx}$. Mutant 10BE proved to be the best producer of the pigment with the yield of astaxanthin amounting to $2.15 \cdot \mathrm{dm}^{-3}$. Illumination above $1,000 \mathrm{~lx}$ inhibited carotenogenesis. Similarly as in the case of biomass, 5,000 lx turned out to critical in this respect. Astaxanthin was the main pigment produced by the tested yeasts irrespective of the culture illumination level. With an increase in illumination intensity its share in the total carotenoids increased by as much as almost $100 \%$ at $1,000-5,0001 \mathrm{~lx}$.

Carotenoid production and accumulation are reported to be positively affected by illumination in many microorganisms. Light generates free oxygen radical and carotenogenesis is considered to be one of the basic photoprotection mechanisms [Bhosale 2004]. According to literature data, light stimulates carotenogenesis and the production of astaxanthin in $X$. dendrorhous. However, its level is very often differently specified. Improved volume yields of carotenoids were reported by Vázquez [2001] in Phaffia rhodozyma flask cultures run under illumination of $500 \mathrm{~lx}$ comparing to cultures run in the dark. De la Fuente et al. [2010] obtained very high yields of biomass and astaxanthin when illuminating flask fermentations from the beginning with ultraviolet and white light of 1,000 1x. In turn, An and Johnson [1990] described a situation when in plate culture strong light inhibited growth and carotenogenesis in yeast $X$. dendrorhous. Tropea et al. [2013] reported that astaxanthin yield of $0.97 \mathrm{~g} \cdot \mathrm{kg}^{-1} \mathrm{DCW}$ was obtained after fed batch cultivation of $X$. dendrorhous in the conventional reactor and in the enlightened reactor lower values, at about $0.93 \mathrm{~g} \cdot \mathrm{kg}^{-1} \mathrm{DCW}$, were found.

Results of the presented experiments indicate that carotenognesis in $X$. dendrorhous DSM 5626 and its mutant is subjected to marked photoregulation and illumination within the range of $600-1,000 \mathrm{~lx}$ promotes carotenogenesis and their production of astaxanthin, while exceeding a certain light capacity results in microbial cell death. Thus at commercial synthesis of astaxanthin using $X$. dendrorhous yeast, the level of culture illumination seems to be a major factor affecting its profitability. Based on the results of this study and those reported in literature sources it may be stated that this parameter needs to be specifically adapted to each strain individually. 
Stachowiak B., 2014. Astaxanthin synthesis by Xanthophyllomyces dendrorhous DSM 5626 and its astaxanthin overproducing mutants on xylose media under different illumination. Acta Sci. Pol., Technol. Aliment. 13(3), 279-288.

Table 2. Effect of illumination on growth and carotenoid production by Xanthophyllomyces dendrorhous DSM 5626 and its mutants in 5-days culture on YM-K medium

\begin{tabular}{|c|c|c|c|c|c|c|}
\hline \multirow{2}{*}{ Parameter } & \multicolumn{6}{|c|}{ Illumination, $1 \mathrm{x}$} \\
\hline & 0 & 300 & 600 & 1000 & 2000 & 5000 \\
\hline \multicolumn{7}{|l|}{ DSM 5626} \\
\hline $\mathrm{DCW}, \mathrm{g} \cdot \mathrm{dm}^{-3}$ & $3.33 \pm 0.06$ & $4.03 \pm 0.05$ & $5.70 \pm 0.08$ & $4.75 \pm 0.02$ & $4.36 \pm 0.15$ & $0.70 \pm 0.12$ \\
\hline \multicolumn{7}{|c|}{ Carotenoids, $\mathrm{mg} \cdot \mathrm{dm}^{-3}$} \\
\hline- total & $0.37 \pm 0.04$ & $1.09 \pm 0.13$ & $1.67 \pm 0.11$ & $1.64 \pm 0.20$ & $1.31 \pm 0.09$ & 0.00 \\
\hline - astaxanthin & $0.32 \pm 0.03$ & $0.98 \pm 0.12$ & $1.60 \pm 0.11$ & $1.57 \pm 0.20$ & $1.28 \pm 0.09$ & 0.00 \\
\hline \multicolumn{7}{|c|}{ Carotenoids, $\mathrm{g} \cdot \mathrm{kg}^{-1} \mathrm{DCW}$} \\
\hline- total & $0.11 \pm 0.01$ & $0.27 \pm 0.03$ & $0.29 \pm 0.02$ & $0.34 \pm 0.04$ & $0.30 \pm 0.01$ & 0.00 \\
\hline - astaxanthin & $0.09 \pm 0.01$ & $0.24 \pm 0.03$ & $0.28 \pm 0.01$ & $0.33 \pm 0.04$ & $0.29 \pm 0.01$ & 0.00 \\
\hline Astaxanthin, \% & 86 & 90 & 96 & 96 & 98 & 0 \\
\hline \multicolumn{7}{|l|}{ 10BE } \\
\hline $\mathrm{DCW}, \mathrm{g} \cdot \mathrm{dm}^{-3}$ & $4.80 \pm 0.01$ & $4.77 \pm 0.31$ & $5.47 \pm 0.06$ & $4.57 \pm 0.05$ & $4.11 \pm 0.10$ & $0.87 \pm 0.05$ \\
\hline \multicolumn{7}{|c|}{ Carotenoids, $\mathrm{mg} \cdot \mathrm{dm}^{-3}$} \\
\hline- total & $1.28 \pm 0.12$ & $1.67 \pm 0.25$ & $2.26 \pm 0.16$ & $1.69 \pm 0.11$ & $1.27 \pm 0.04$ & 0.00 \\
\hline - astaxanthin & $1.22 \pm 0.11$ & $1.59 \pm 0.24$ & $2.15 \pm 0.15$ & $1.62 \pm 0.11$ & $1.22 \pm 0.04$ & 0.00 \\
\hline \multicolumn{7}{|c|}{ Carotenoids, $\mathrm{g} \cdot \mathrm{kg}^{-1} \mathrm{DCW}$} \\
\hline- total & $0.27 \pm 0.02$ & $0.35 \pm 0.03$ & $0.41 \pm 0.03$ & $0.37 \pm 0.03$ & $0.31 \pm 0.01$ & 0.00 \\
\hline - astaxanthin & $0.25 \pm 0.02$ & $0.33 \pm 0.03$ & $0.39 \pm 0.02$ & $0.36 \pm 0.03$ & $0.30 \pm 0.01$ & 0.00 \\
\hline Astaxanthin, \% & 95 & 95 & 95 & 96 & 96 & 0 \\
\hline \multicolumn{7}{|l|}{$26 U V$} \\
\hline DCW, $g \cdot \mathrm{dm}^{-3}$ & $1.80 \pm 0.15$ & $3.33 \pm 0.32$ & $5.10 \pm 0.17$ & $3.43 \pm 0.03$ & $3.37 \pm 0.06$ & $0.77 \pm 0.06$ \\
\hline \multicolumn{7}{|c|}{ Carotenoids, $\mathrm{mg} \cdot \mathrm{dm}^{-3}$} \\
\hline- total & $0.39 \pm 0.05$ & $1.46 \pm 0.29$ & $1.94 \pm 0.16$ & $1.85 \pm 0.04$ & $0.81 \pm 0.08$ & $0.10 \pm 0.02$ \\
\hline - astaxanthin & $0.27 \pm 0.04$ & $1.23 \pm 0.24$ & $1.82 \pm 0.15$ & $1.76 \pm 0.04$ & $0.78 \pm 0.07$ & $0.10 \pm 0.02$ \\
\hline \multicolumn{7}{|c|}{ Carotenoids, $\mathrm{g} \cdot \mathrm{kg}^{-1} \mathrm{DCW}$} \\
\hline- total & $0.22 \pm 0.02$ & $0.44 \pm 0.05$ & $0.38 \pm 0.02$ & $0.54 \pm 0.01$ & $0.24 \pm 0.02$ & $0.13 \pm 0.01$ \\
\hline - astaxanthin & $0.15 \pm 0.01$ & $0.37 \pm 0.04$ & $0.36 \pm 0.02$ & $0.51 \pm 0.01$ & $0.23 \pm 0.02$ & $0.13 \pm 0.01$ \\
\hline Astaxanthin, \% & 68 & 84 & 94 & 95 & 96 & 97 \\
\hline
\end{tabular}


Stachowiak B., 2014. Astaxanthin synthesis by Xanthophyllomyces dendrorhous DSM 5626 and its astaxanthin overproducing mutants on xylose media under different illumination. Acta Sci. Pol., Technol. Aliment. 13(3), 279-288.

\section{CONCLUSIONS}

Presented results reveal that (1) astaxanthin synthesis in $X$. dendrorhous DSM 5626 and its mutants was better in YM-K medium comparing to hydrolysed rye stillage, (2) carotenogenesis in the studied yeast strains was subjected to marked photoregulation and (3) illumination within the range of 600-1,000 lx promotes carotenogenesis and astaxanthin production, while exceeding a certain light capacity results in microbial cell death.

\section{REFERENCES}

An G.H., Johnson E.A., 1990. Influence of light on growth and pigmentation of the yeast Phaffia rhodozyma. Antonie van Leeuwenhoek J. Microbiol. 57, 191-203.

Ananda N., Vadlani P.V., 2010. Production and optimization of carotenoid-enriched dried distiller's grains with solubles by Phaffia rhodozyma and Sporobolomyces roseus fermentation of whole stillage. J. Ind. Microbiol. Biotechnol. 37, 1183-1192.

Bhosale P., 2004. Environmental and cultural stimulants in the production of carotenoids from microorganisms. Appl. Microbiol. Biotechnol. 63, 351-361.

Bon J.A., Leathers T.D., Jayaswal R.K., 1997. Isolation of astaxanthin-overproducing mutants of Phaffia rhodozyma. Biotechnol. Lett. 19, 109-112.

Breithaupt D.E., 2007. Modern application of xanthophylls in animal feeding - a review. Trends Food Sci. Technol. 18, 501-506.

Cruz J.M., Parajó J.C., 1998. Improved astaxanthin production by Xanthophyllomyces dendrorhous growing on enzymatic wood hydrolysates containing glucose and cellobiose. Food Chem. 63 (4), 479-484.

De la Fuente J.L., Rodríguez-Sáiz M., Schleissner C., Díez B., Peiro E., Barredo J.L., 2010. High-titer production of astaxanthin by the semi-industrial fermentation of Xanthophyllomyces dendrorhous. J. Biotechnol. 148, 144-146.

Flores-Cotera L.B., Martín R., Sánchez S., 2001. Citrate, a possible precursor of astaxanthin in Phaffia rhodozy$m a$ : influence of varying levels of ammonium, phosphate and citrate in chemically defined medium. Appl. Microbiol. Biotechnol. 55, 341-347.

Goswami G., Chaudhuri S., Dutta D., 2010. The present perspective of astaxanthin with reference to biosynthesis and pharmacological importance. World J. Microbiol. Biotechnol. 26, 1925-1939.
Gramza-Michałowska A., Stachowiak B., 2010. The antioxidant potential of carotenoid extract from Phaffia rhodozyma. Acta Sci. Pol., Technol. Aliment. 9 (2), 171-188.

Handbook of photometrical operation analysis. 2000. Dr. Lange, BDB 079 [in German].

Hu Z.C., Zheng Y.G., Wang Z., Shen Y.C., 2005. Effect of sugar-feeding strategies on astaxanthin production by Xanthophyllomyces dendrorhous. World J. Microbiol. Biotechnol. 21, 771-775.

Karppi J., Rissanen T.H., Nyyssönen K., Kaikkonen J., Olsson A.G., Voutilainen S., Salonen J.T., 2007. Effects of astaxanthin supplementation on lipid peroxidation. Int. J. Vitam. Nutr. Res. 77, 3-11.

Krzywonos M., Cibis E., Miśkiewicz T., Ryznar-Luty A., 2009. Utilization and biodegradation of starch stillage (distillery wastewater). Electr. J. Biotechnol. 12 (1), $1-12$.

Leathers T.D., 2003. Bioconversions of maize resiudes to value-added coproducts using yeast-like fungi. FEMS Yeast Res. 3, 133-140.

Liu X.B., Osawa T., 2007. Cis astaxanthin and especially 9-cis astaxanthin exhibits a higher antioxidant activity in vitro compared to the all-trans isomer. Biochem. Biophys. Res. Commun. 357, 187-193.

McNulty H.P., Byun J., Lockwood S.F., Jacob R.F., Mason R.P., 2007. Differential effects of carotenoids on lipid peroxidation due to membrane interactions: X-ray diffraction analysis. Biochim. Biophys. Acta 1768 (1), 167-174.

Montanti J.M., Nghiem N.P., Johnston D., 2011. Production of astaxanthin from cellulosic biomass sugars by mutants of the yeast Phaffia rhodozyma. Appl. Biochem. Biotechnol. 164, 655-665.

Palágyi Z.S., Ferenczy L., Vágvölgyi C.S., 2001. Carbonsource assimilation pattern of astaxanthin-producing yeast Phaffia rhodozyma. World J. Microbiol. Biotechnol. 17, 95-97.

Parajó J.C., Santos V., Vázquez M., Cruz J.M., 1997. Production of carotenoids by Xanthophyllomyces dendrorhous growing on enzymatic hydrolysates of prehydrolysed wood. Food Chem. 60 (3), 347-355.

Parajó J.C., Santos V., Vázquez M., 1998. Optimization of carotenoid production by Phaffia rhodozyma cells grown on xylose. Process Biochem. 33 (2), 181-187.

Pashkow F.J., Watumull D.G., Campbell C.L., 2008. Astaxanthin: a novel potential treatment for oxidative stress and inflammation in cardiovascular disease. Am. J. Cardiol. 101 (10A), 58D-68D. 
Stachowiak B., 2014. Astaxanthin synthesis by Xanthophyllomyces dendrorhous DSM 5626 and its astaxanthin overproducing mutants on xylose media under different illumination. Acta Sci. Pol., Technol. Aliment. 13(3), 279-288.

Reynders M.B., Rawling D.E., Harrison S.T.I., 1997. Demonstration of the Crabtree effect in Phaffia rhodozyma during continuous and fed-batch cultivation. Biotechnol. Lett. 19, 549-552.

Rodrigues E., Mariutti L.R., Mercadante A.Z., 2012. Scavenging capacity of marine carotenoids against reactive oxygen and nitrogen species in a membrane-mimicking system. Mar. Drugs 10 (8), 1784-1798.

Schmidt I., Schewe H., Gassel S., Jin C., Buckingham J., Hümbelin M., Sandmann G., Schrader J., 2011. Biotechnological production of astaxanthin with Phaffia rhodozyma/Xanthophyllomyces dendrorhous. Appl. Microbiol. Biotechnol. 89, 555-571.

Stachowiak B., 2012. Astaxanthin synthesis by yeast Xanthophyllomyces dendrorhous and its mutants on media based on plant extracts. Indian J. Microbiol. 52 (4), 654-659.

Stachowiak B., 2013 a. Efficiency of selected mutagens in generating Xanthophyllomyces dendrorhous strains hyperproducing astaxanthin. Polish J. Microbiol. 62 (1), 67-72.

Stachowiak B., 2013 b. The effect of illumination intensities on astaxanthin synthesis by Xanthophyllomyces dendrorhous and its mutants. Food Sci. Biotechnol. 22 (4), 1-6.

Szwengiel A., Czarnecka M., Czarnecki Z., 2007. Levan synthesis during associated action of levansucrase and Candida cacaoi DSM 2226 yeast. Polish J. Food Nutr. Sci. 57 (4), 433-440.
Takahashi K., Watanabe M., Takimoto T., Akiba Y., 2004. Uptake and distribution of astaxanthin in several tissues and plasma lipoproteins in male broiler chickens fed a yeast (Phaffia rhodozyma) with a high concentration of astaxanthin. Brit. Poultry Sci. 45 (1), 133-138.

Tropea A., Gervasi T., Melito M.R., Curto A.L., Curto R.L., 2013. Does the light influence astaxanthin production in Xanthophyllomyces dendrorhous? Nat. Prod. Res. 27 (7), 648-654.

Vázquez M., 2001. Effect of the light on carotenoid profiles of Xanthophyllomyces dendrorhous strains (formerly Phaffia rhodozyma). Food Technol. Biotechnol. 39 (2), 123-128.

Vázquez M., Santos V., Paraja J.C., 1997. Effect of the carbon source on carotenoid profiles of Phaffia rhodozyma strains. J. Indust. Microbiol. Biotechnol. 19, 263-268.

Vustin M.M., Belykh E.N., Kishilova S.A., 2004. Relationnship between astaxanthin production and the intensity of anabolic process in the yeast Phaffia rhodozyma. Microbiology 73 (6), 751-757.

Xu X., Jin Z., Wang H., Chen X., Wang C., Yu S., 2006. Effect of astaxanthin from Xanthophyllomyces denrorhous on the pigmentation of goldfish, Carassiuus auratus. J. World Aquacult. Soc. 37 (3), 282-288.

Yuan J.P., Peng J., Yin K., Wang J.H., 2011. Potential healthpromoting effects of astaxanthin: A high-value carotenoid mostly from microalgae. Mol. Nutr. Food Res. 55, 150-165.

\section{SYNTEZA ASTAKSANTYNY PRZEZ XANTHOPHYLLOMYCES DENDRORHOUS DSM 5626 I JEGO NADPRODUKUJĄCE ASTAKSANTYNĘ MUTANTY NA PODŁOŻACH Z KSYLOZĄ, PRZY RÓŻNYM NATĘŻENIU OŚWIETLENIA}

\section{STRESZCZENIE}

Wstęp. Astaksantyna jest najważniejszym i najdroższym karotenoidem stosowanym w akwakulturze. Jej komercyjna atrakcyjność wynika również z wysokiego potencjału przeciwutleniającego. Obecnie drożdże Xanthophyllomyces dendrorhous wydają się najbardziej obiecującymi mikroorganizmami w przemysłowej produkcji tego barwnika. Celem pracy było zbadanie możliwości wzrostu i produkcji astaksantyny przez szczepy $X$. dendrorhous w hodowlach na podłożach z ksylozą oraz zbadanie wpływu oświetlenia na karotenogenezę. Materiat i metody. W badaniach użyto szczep X. dendrorhous DSM 5626 oraz jego mutanty: 10BE i 26UV. Hodowle przeprowadzono na zhydrolizowanym wywarze żytnim (HS) i na podłożu YM z ksylozą (YM-K). Po pięciu dniach w hodowlach kontrolowano: wydajność biomasy oraz komórkową i objętościową wydajność karotenoidów i astaksantyny. W hodowlach na podłożu YM-K oceniano również wpływ natężenia oświetlenia w zakresie 0-5000 lx na wzrost drożdży i karotenogenezę.

Wyniki. Dla badanych szczepów drożdży lepsze parametry wzrostu i wydajności astaksantyny odnotowano w hodowlach na podłożu YM-K niż na HS. W hodowlach na podłożu YM-K najlepsze wydajności astaksantyny uzyskano przy natężeniu oświetlenia 600-1000 lx. Największą komórkową koncentrację 
Stachowiak B., 2014. Astaxanthin synthesis by Xanthophyllomyces dendrorhous DSM 5626 and its astaxanthin overproducing mutants on xylose media under different illumination. Acta Sci. Pol., Technol. Aliment. 13(3), 279-288.

astaksantyny odnotowano dla szczepu 26UV w hodowli przy $1000 \mathrm{~lx}\left(0,51 \mathrm{~g} \cdot \mathrm{kg}^{-1} \mathrm{DCW}\right)$, natomiast objętościową dla 10BE, w hodowli przy $600 \mathrm{~lx}\left(2,15 \mathrm{mg} \cdot \mathrm{dm}^{-3}\right)$.

Wnioski. Badane szczepy $X$. dendrorhous DSM 5626 i jego mutanty rosły lepiej i syntetyzowały więcej astaksantyny na podłożu YM-K niż na zhydrolizowanym wywarze żytnim. Ponadto u badanych drożdży karotenogeneza podlegała silnej fotoregulacji. Natężenie oświetlenia w zakresie 600-1000 lx sprzyjało syntezie karotenoidów, w tym astaksantyny.

Słowa kluczowe: Xanthophyllomyces dendrorhous, astaksantyna, synteza karotenoidów, natężenie oświetlenia, ksyloza

Received - Przyjęto: 28.02.2014

Accepted for print - Zaakceptowano do druku: 9.04.2014

For citation - Do cytowania

Stachowiak B., 2014. Astaxanthin synthesis by Xanthophyllomyces dendrorhous DSM 5626 and its astaxanthin overproducing mutants on xylose media under different illumination. Acta Sci. Pol., Technol. Aliment. 13(3), 279-288. 